\title{
Evaluation of microalgae as sources of digestible nutrients for monogastric animals*
}

\author{
A. Skrede ${ }^{1,5}$, L.T. Mydland ${ }^{1}$, Ø. Ahlstrøm², K.I. Reitan ${ }^{4}$, \\ H.R. Gislerød ${ }^{3}$ and M. Øverland ${ }^{1}$
}

\author{
Norwegian University of Life Sciences, \\ ${ }^{1}$ Aquaculture Protein Centre, CoE, Department of Animal and Aquacultural Sciences, \\ ${ }^{2}$ Department of Animal and Aquacultural Sciences, \\ ${ }^{3}$ Department of Plant and Environmental Sciences \\ P.O. Box 5003, N-1432 As \\ ${ }^{4}$ SINTEF Fisheries and Aquaculture \\ N-7465 Trondheim, Norway
}

(Received 26 January 2011; revised version 3 March 2011; accepted 12 March 2011)

\begin{abstract}
The study was carried out to evaluate three microalgae as potential nutrient sources in diets for monogastric animals. In a digestibility experiment with adult mink (Mustela vison), the microalgae Nannochloropsis oceanica, Phaeodactylum tricornutum and Isochrysis galbana were fed at 60, 120 and $240 \mathrm{~g} \mathrm{~kg}^{-1}$ as is, replacing fish meal. The $N$. oceanica and P. tricornutum had similar crude protein (CP) content (47.7 and $49.0 \%$ of DM, respectively), amino acid composition and lipid content ( 8.4 and $7.4 \%$, respectively), whereas I. galbana contained $20.1 \% \mathrm{CP}$ and $16.2 \%$ lipids. There was a significant linear reduction in CP digestibility with increasing dietary inclusion of all algae products. The apparent $\mathrm{CP}$ digestibility determined by linear regression for $N$. oceanica, $P$. tricornutum and I. galbana was 35.5, 79.9 and $18.8 \%$, respectively. The individual amino acid digestibilities showed acceptable values for P. tricornutum, but low and highly variable values for $N$. oceanica and I. galbana. Although the algae contributed a minor proportion of dietary lipids, lipid digestibility declined with increasing inclusion of all algae and especially with the highest level of $N$. oceanica. It was concluded from the mink study that among the investigated algae, P. tricornutum was the preferable source of digestible nutrients.
\end{abstract}

KEY WORDS: algae, protein, amino acids, lipid, digestibility, mink

\footnotetext{
* Supported by the Research Council of Norway, Grant No. 172580/S40 "Potential of using microalgae to partially replace fish oil and fish meal in aquaculture fish feeds"

${ }^{5}$ Corresponding author: e-mail: anders.skrede@umb.no
} 


\section{INTRODUCTION}

The increasing awareness of limitations in cultivatable land areas and the fact that the catches of pelagic fisheries are limited, emphasizes the need to explore the potential of untraditional and sustainable animal feed ingredients. In the search for alternative nutrient sources, microalgae have been considered promising sources of protein and lipids (Spolaore et al., 2006; Becker, 2007). Microalgae may have a protein content of $20-60 \%$ of dry matter and variable contents of lipids, depending on species and growth conditions (Reitan et al., 1994; Brown et al., 1997). Production of microalgae may therefore have a potential to be a suitable source for partial replacement of protein and lipids in animal feed. At present, several species of microalgae are mainly used as live feed in aquaculture (Brown et al., 1997; Brown, 2002), whereas about $30 \%$ of the current algal production is used in feed for poultry and other terrestrial animals (Becker, 2007).

The application of microalgae as a future nutrient source for the animal feed industry depends on detailed information on parameters such as chemical composition and digestibility. The microalgae species Nannochloropsis oceanica, Phaeodactylum tricornutum and Isochrysis galbana are all used for bivalve molluscs, for the larval and early juvenile stages of crustaceans and certain fish species, and for zooplankton used in aquaculture food chains (Yamaguchi, 1997; Brown, 2002), and it seems interesting to study whether these algae are applicable also in compound feed for monogastric animals. The objective of the present study was to investigate the effect of increasing dietary inclusion of $N$. oceanica, P. tricornutum and I. galbana on digestibility of crude protein, amino acids and lipids in mink (Mustela vison). The authors are unaware of previous studies in which digestibility of microalgae in mink has been studied. The carnivorous mink was used as model animal due to the documented relationship with digestibility in salmonid fish and other monogastric species (Skrede et al., 1998).

\section{MATERIALAND METHODS}

Algae products tested

The $N$. oceanica was isolated from an operational hatchery in western Norway and cultivated in three tubular photobioreactor biofence systems, each of 2001 volume, at Norwegian University of Life Sciences, Ås (Sandnes et al., 2005). The P. tricornutum was obtained from Fitoplankton Marino (Spain), and I. galbana from Reed Mariculture, Campbell, California (USA). The biomass of all three microalgae was freeze-dried prior to analysis and feed manufacturing. 


\section{Animals and diets}

The digestibility experiment was carried out at the Department of Animal and Aquacultural Sciences, Norwegian University of Life Sciences, Ås.

Adult male mink of the standard dark genotype were randomly allotted to 10 groups of four animals each. The mink were housed individually in cages equipped for controlled feeding and quantitative faecal collection, avoiding contamination with urine, in a ventilated room with controlled temperature and light conditions. The animals had continuous access to water. All mink were cared for according to laws and regulations controlling experiments with live animals in Norway (i.e. the Animal Protection Act of December 20, 1974, and the Animal Protection Ordinance concerning experiments with animals of January 15, 1996).

Ten different diets were used in the experiment. In the control diet (diet 1) high quality fish meal was used as the sole source of protein (Table 1). In diets 2, 3 and $4, N$. oceanica was added at levels of 60,120 and $240 \mathrm{~g} \mathrm{~kg}^{-1}$ as is, respectively, replacing fish meal. Correspondingly in diets 5, 6 and 7, P. tricornutum was added at 60,120 and $240 \mathrm{~g} \mathrm{~kg}^{-1}$, respectively. In diets 8,9 and 10, I. galbana was added at 60,120 and $240 \mathrm{~g} \mathrm{~kg}^{-1}$, respectively, replacing fish meal.

Table 1. Ingredient composition of control diet

\begin{tabular}{lc}
\hline Ingredients & $\mathrm{g} \mathrm{kg}^{-1}$ as fed \\
\hline Fish meal ${ }^{1}$ & 491.8 \\
Maize starch (precooked) & 234.2 \\
Soyabean oil $^{2}$ & 234.2 \\
Cellulose powder $^{\text {Vitamin and mineral premix }}{ }^{3}$ & 37.5 \\
Water $^{4}$ & 2.3 \\
\hline
\end{tabular}

${ }^{1}$ Norse LT-94, low-temperature dried fish meal, Norsildmel, Bergen, Norway; ${ }^{2}$ Denofa AS, Fredrikstad, Norway; ${ }^{3}$ Norsk Mineralnæring, Hønefoss, Norway. Ingredients per kg: IU: vit. A 2000 000, vit. D 200 000; mg: vit. E 50 000, vit. B 15000 , vit. B 3000 , vit. B 3000 , vit. $B_{12}$ 20, pantothenic acid 3000 , niacin 5000 , biotin 30, folic acid 300, Fe (amino acid-chelated) 20000 , $\mathrm{Zn}$ oxide 7 500, Mn oxide 15000 and $\mathrm{Cu}$ sulphate $1250 ;{ }^{4}$ added to suitable diet concistency

Proximate composition of diets and calculated percentage contribution of the algae to the total dietary content of $\mathrm{CP}$ and lipids are shown in Table 2. The control diet and diets containing $N$. oceanica and P. tricornutum were nearly isonitrogenous on a DM basis, whereas the crude protein content of the diets containing I. galbana declined slightly with increasing algae inclusion due to the low protein content of this alga. All diets had similar total lipid contents.

All diets were prepared prior to start of the experiment, weighed into plastic cups in individual daily rations, and stored frozen at $-22^{\circ} \mathrm{C}$ until thawing in a refrigerator starting about $20 \mathrm{~h}$ before feeding. The diets were fed for 7 days 3 days of adaptation followed by 4 days of total faecal collection (Skrede, 1979; 
Table 2. Analysed proximate composition of freeze-dried diets $\left(\mathrm{g} \mathrm{kg}^{-1}\right)$ and dietary proportion of crude protein and lipids from microalgae, $\%$

\begin{tabular}{lcccccccccc}
\hline & Control & \multicolumn{3}{c}{ N. oceanica } & \multicolumn{3}{c}{ P. tricornutum } & \multicolumn{3}{c}{ I. galbana } \\
\hline Iiet & 1 & 2 & 3 & 4 & 5 & 6 & 7 & 8 & 9 & 10 \\
Dry matter, $\mathrm{g} \mathrm{kg}^{-1}$ & 976 & 971 & 980 & 979 & 974 & 981 & 979 & 972 & 963 & 957 \\
$\begin{array}{l}\text { In dry matter, } \mathrm{g} \mathrm{kg}^{-1} \\
\quad\end{array}$ & & & & & & & & & \\
$\quad$ crude protein & 378 & 359 & 347 & 313 & 359 & 347 & 317 & 347 & 301 & 241 \\
$\quad$ lipid & 311 & 307 & 306 & 301 & 306 & 305 & 299 & 314 & 303 & 311 \\
$\quad$ starch & 229 & 232 & 236 & 237 & 227 & 229 & 231 & 231 & 236 & 229 \\
$\quad$ ash & 79 & 72 & 62 & 60 & 84 & 83 & 77 & 84 & 105 & 120 \\
$\quad$ organic matter & 897 & 899 & 918 & 919 & 890 & 898 & 902 & 888 & 858 & 837 \\
Part of nutrient from & algae, \% & & & & & & & & & \\
$\quad$ crude protein & 0 & 7.7 & 16.1 & 35.2 & 8.1 & 16.7 & 36.4 & 3.4 & 7.0 & 17.9 \\
$\quad$ lipid & 0 & 1.61 & 3.24 & 6.40 & 1.45 & 2.91 & 5.86 & 2.87 & 5.68 & 11.5 \\
\hline
\end{tabular}

Szymeczko and Skrede, 1990). The individual daily feed intake was recorded; as feed offered minus feed rejected. Feeding, collection of feed residues and collection of faeces were carried out once daily. Pooled faeces from each animal were freeze-dried, ground, and sifted for removal of hair pending analyses.

\section{Chemical analysis}

For chemical analysis, samples of all experimental diets and individually pooled faeces were freeze-dried and ground through a $0.5 \mathrm{~mm}$ screen. Diets and faecal samples were analysed using standard methods for the European Community: dry matter (71/393/EEC), ash (71/250/EEC), crude protein (Kjeldahl-N x 6.25; 93/28/ EEC), amino acids (98/64/EC) and tryptophan (2000/45/EC). Crude lipid was determined by extraction with petroleum ether in an Accelerated Solvent Extractor (ASE200) from Dionex (Sunnyvale, CA, USA). Starch was determined as glucose after hydrolysis (McCleary et al., 1984). Organic matter was calculated as: DM ash. All ingredients, diets, and faecal samples were analysed in triplicates.

\section{Calculations and statistics}

Apparent total tract digestibility (\%) was calculated for each individual animal as:

$$
((a-b) / a) \times 100
$$

where: $\mathrm{a}$ - nutrient intake and b - amount of nutrient in faeces.

Statistical analysis was performed by the GLM procedure of SAS (1990) with each mink as the experimental unit. Results are presented as least squares mean (LSmeans) for each diet, and variance is expressed as standard error of the mean 
(SEM) for each series of algae inclusion or standard deviation (SD) for treatment groups. Duncan's multiple range test was used to test differences in digestibility between diets. The significance level was set to $\mathrm{P}<0.05$.

\section{RESULTS AND DISCUSSION}

\section{Proximate composition and amino acid profile}

The chemical composition of microalgal biomass is affected by species and cultivation methods, and may be manipulated readily by changing growth conditions (Brown et al., 1997; Fàbregas et al., 1998; Rebolloso-Fuentes et al., 2001). The proximate composition and amino acid profiles of the algae products used in our study in a comparison with LT fish meal are shown in Table 3. The

Table 3. Proximate composition and amino acid contents of fish meal and the microalgae Nannochloropsis oceanica, Phaeodactylum tricornutum and Isochrysis galbana

\begin{tabular}{|c|c|c|c|c|}
\hline Algae & Fish meal & N. oceanica & P. tricornutum & I.galbana \\
\hline \multicolumn{5}{|l|}{$\overline{\text { Proximate composition }}$} \\
\hline dry matter, $\mathrm{g} \mathrm{kg}^{-1}$ & 927 & 949 & 970 & 888 \\
\hline crude protein, $\mathrm{g} \mathrm{kg}^{-1} \mathrm{DM}$ & 747 & 477 & 490 & 201 \\
\hline fat, $\mathrm{g} \mathrm{kg}^{-1} \mathrm{DM}$ & 96.6 & 84.1 & 73.7 & 162 \\
\hline starch, $\mathrm{g} \mathrm{kg}^{-1} \mathrm{DM}$ & 0.0 & 0.3 & 0.3 & 0.1 \\
\hline ash, $\mathrm{g} \mathrm{kg}^{-1} \mathrm{DM}$ & 147 & 74.8 & 158 & 310 \\
\hline organic matter, $\mathrm{g} \mathrm{kg}^{-1} \mathrm{DM}$ & 780 & 874 & 812 & 578 \\
\hline \multicolumn{5}{|c|}{ Essential amino acids, $g 16 \mathrm{~g}^{-1} \mathrm{~N}^{*}$} \\
\hline lysine & 6.8 & 4.8 & 4.2 & 3.1 \\
\hline threonine & 3.5 & 3.6 & 3.7 & 4.6 \\
\hline methionine & 2.5 & 1.8 & 2.0 & 2.5 \\
\hline tryptophan & 0.7 & 1.7 & 1.3 & 2.5 \\
\hline valine & 4.0 & 4.6 & 4.6 & 6.1 \\
\hline isoleucine & 3.7 & 3.5 & 3.8 & 5.1 \\
\hline leucine & 6.2 & 6.7 & 6.2 & 9.2 \\
\hline phenylalanine & 3.3 & 3.9 & 4.2 & 5.7 \\
\hline histidine & 1.7 & 1.5 & 1.2 & 1.7 \\
\hline arginine & 5.4 & 4.9 & 4.4 & 4.1 \\
\hline \multicolumn{5}{|c|}{ Non-essential amino acids, $g 16 \mathrm{~g}^{-1} \mathrm{~N}^{*}$} \\
\hline aspartic acid + asparagine & 8.1 & 7.0 & 8.1 & 9.7 \\
\hline serine & 3.7 & 3.3 & 3.5 & 4.2 \\
\hline glutamic acid + glutamine & 12.2 & 9.7 & 10.2 & 11.3 \\
\hline proline & 3.3 & 9.8 & 4.5 & 4.9 \\
\hline glycine & 4.7 & 3.8 & 3.7 & 5.2 \\
\hline alanine & 4.8 & 5.2 & 5.6 & 6.6 \\
\hline tyrosine & 2.5 & 2.4 & 2.5 & 0.3 \\
\hline cysteine + cystine & 0.8 & 0.7 & 0.8 & 1.0 \\
\hline
\end{tabular}

* determined using water-corrected molecular weights 
$N$. oceanica and $P$. tricornutum had a lower content of CP than fish meal, but comparable contents of lipids. The CP content of P. tricornutum was similar to results obtained by Miròn et al. (2003) but higher than reported by Brown (1991), whereas the lipid content was lower than observed by Brown (1991) and Alonso et al. (2000). The I. galbana had lower CP content compared with the other algae, about twice as high lipid content, and very high ash content. The relatively low protein content and high lipid content in I. galbana is in line with other studies (Sànchez et al., 2000; Pettersen et al., 2010).

According to Brown (1991), the amino acid composition of different microalgae species is similar, and relatively unaffected by conditions of cultivation. In the present study, all species had a profile of essential amino acids similar to fish meal, except that content of lysine was lower and tryptophan content higher in the algae. The P. tricornutum used in our study had similar amino acid profile as reported by Brown (1991). The contents of amino acids in I. galbana agreed mostly with results obtained by Epifanio (1979), Brown (1991) and Brown et al. (1993), but our data revealed lower contents of lysine, arginine and tyrosine compared with the latter studies.

\section{Digestibility}

Inclusion of the different algae in mink diets did not appear to affect diet palatability, as all diets were well accepted by the mink. Average feed intake is shown in Table 4. One animal fed the lowest level of $N$. oceanica was omitted from the experiment due to low feed intake. The average feed intake in different treatment groups amounted to $96-99 \%$ of feed offered and was not correlated to inclusion level of any of the algae. Increasing inclusion of all algae products caused a slightly softer faecal consistency.

Substitution of LT fish meal with increasing amounts of $N$. oceanica and $I$. galbana, and to a lesser extent $P$. tricornutum, significantly lowered digestibility of CP and lipids in mink (Table 4). Addition of I. galbana and the lowest level of $P$. tricornutum significantly increased digestibility of starch (Table 4). However, the starch was generally very well digested, as might be expected from the use of precooked maize starch as almost the sole source of starch in all diets.

There was a significant adverse effect on the apparent CP digestibility even at the lowest level of $N$. oceanica and I. galbana $\left(60 \mathrm{~g} \mathrm{~kg}^{-1}\right)$, but a significant negative effect of $P$. tricornutum only appeared at the two highest levels. Regression analyses showed linear relationships between algae inclusion and apparent $\mathrm{CP}$ digestibility (Figure 1). The apparent $\mathrm{CP}$ digestibility in algae estimated by linear regression and extrapolation to $100 \%$ of CP from algae, was $35.5 \%$ for N. oceanica, $79.9 \%$ for P. tricornutum and $18.8 \%$ for I. galbana. The 


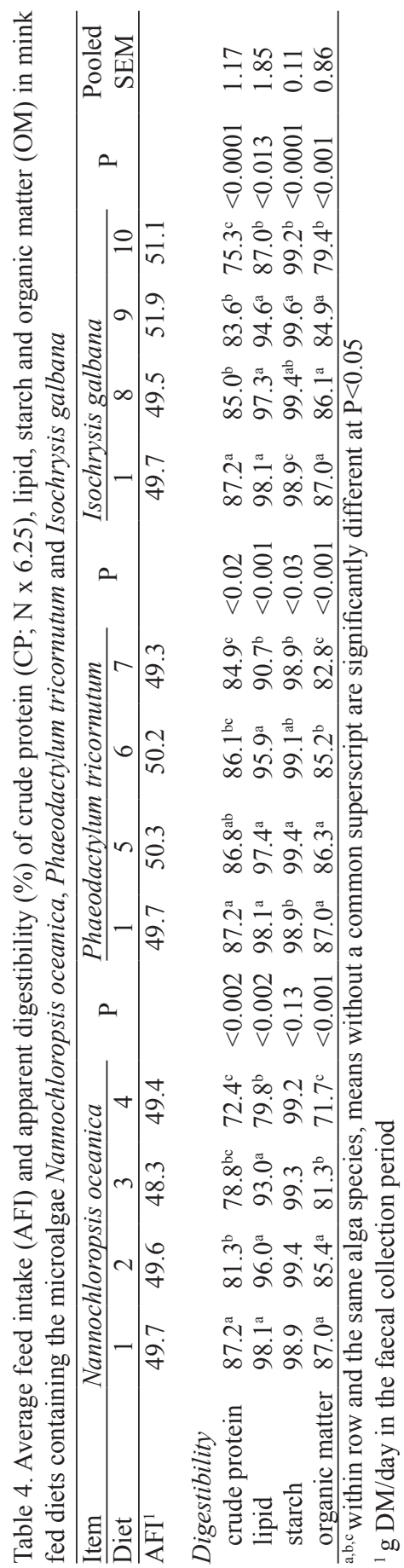



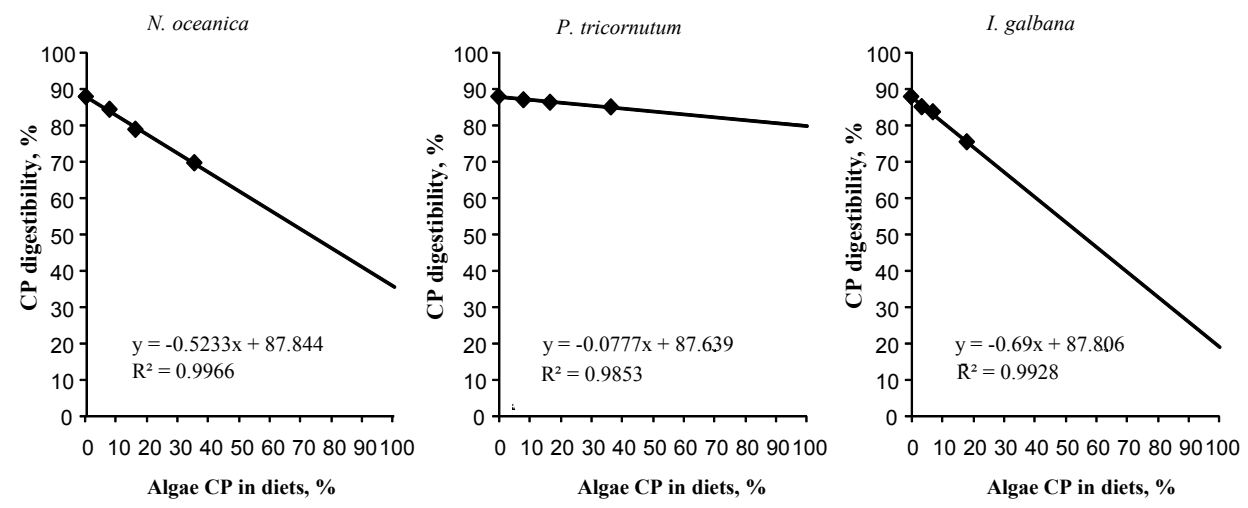

Figure 1. Regression lines for apparent digestibility of $\mathrm{CP}$ in the three microalgae $(\mathrm{y}=$ apparent digestibility of a diet with $\mathrm{x} \%$ of $\mathrm{CP}$ from the algae)

apparent CP digestibility of $P$. tricornutum was lower than for high quality fish meal, but comparable with the $\mathrm{CP}$ digestibilities of common plant protein sources such as soyabean meal and rapeseed meal. The estimated CP digestibilities of $N$. oceanica and I. galbana must be considered as very low and probably unacceptable for feed ingredients intended for monogastric animals. Especially for I. galbana, it should be pointed out that the rather low contribution to total dietary $\mathrm{CP}$, reduces the accuracy of extrapolation when assuming linearity in digestibility up to $100 \%$ of dietary CP. The poor CP digestibility of N. oceanica and I. galbana may be caused by the resistance of the thick and rigid algal cell wall to disruption by digestive processes (Becker, 2007; Marshall et al., 2010). Although there are no previous digestibility studies with mink, studies with other animals indicate that the digestibility of several algae species is dependent on disrupting the algal cell wall by proper processing (Saleh et al., 1985; Janczyk et al., 2005). Even after cell wall disruption, inherent proteins in the cell wall matrix may be protected against attack by digestive proteolytic enzymes, and advanced technological treatment increases the cost of the algae product. The freeze-drying of algae used in our study probably maintained the cell structure of the N. oceanica and I. galbana without any cell wall disruption. The cell wall of diatoms as $P$. tricornutum consist of silicon and may be more easily broken during digestion. However, some studies indicate that preserving of microalgae such as P. tricornutum by freezing or freezedrying may lower digestibility due to altering the cell wall or compacting the algal cell (Albentosa et al., 1997).

The apparent digestibilities of amino acids in the algae species, using linear regression and the individual contribution of amino acids from algae to total dietary amino acid intake, are shown in Table 5. The P. tricornutum revealed 
substantially higher digestibility of potentially limiting essential amino acids such as methionine, lysine and tryptophan compared with $N$. oceanica and $I$. galbana, thus confirming the $\mathrm{CP}$ digestibility data indicating that $P$. tricornutum was a better source of digestible amino acids than the other algae. The calculated amino acid digestibilities of I. galbana were rather variable, and especially lysine and cysteine (negative value) were poorly digested. However, I. galbana contributed minor proportions of total dietary amino acids; hence reducing the precision in the regression calculations of individual amino acid digestibilities.

Table 5. Average apparent amino acid digestibility (\%) of LT fish meal and the algae Nannochloropsis oceanica, Phaeodactylum tricornutum and Isochrysis galbana ${ }^{1}$

\begin{tabular}{lcccc}
\hline Amino acids & Fish meal & N. oceanica & P. tricornutum & I. galbana \\
\hline Essential amino acids & & & & \\
$\quad$ lysine & 86.8 & 38.1 & 84.5 & 12.6 \\
threonine & 85.0 & 50.1 & 83.0 & 55.0 \\
methionine & 93.5 & 35.6 & 83.4 & 64.8 \\
tryptophan & 85.6 & 38.3 & 81.7 & 69.0 \\
valine & 91.4 & 31.6 & 82.2 & 62.5 \\
isoleucine & 92.4 & 30.3 & 75.9 & 63.5 \\
leucine & 93.0 & 30.9 & 81.6 & 68.6 \\
phenylalanine & 90.3 & 31.9 & 83.2 & 69.2 \\
histidine & 88.9 & 17.2 & 76.6 & 37.1 \\
arginine & 93.6 & 41.2 & 87.4 & 56.8 \\
Non-essential amino acids & & & & \\
aspartic acid + asparagine & 82.3 & 37.7 & 81.4 & 60.0 \\
serine & 88.3 & 35.0 & 76.4 & 49.4 \\
glutamic acid+ glutamine & 92.1 & 42.8 & 84.1 & 52.4 \\
proline & 88.7 & 78.9 & 88.1 & 60.5 \\
glycine & 88.3 & 39.7 & 88.8 & 54.7 \\
alanine & 91.8 & 30.3 & 78.6 & 61.8 \\
tyrosine & 80.9 & 22.7 & 58.7 & 77.0 \\
cysteine + cystine & 71.7 & 58.8 & 54.7 & -13.1 \\
\hline determined directly (fish meal) or by linear regression (microalgae) & &
\end{tabular}

Lipids are important storage components of microalgae, and several species are considered as promising sources of long-chain PUFAs such as EPA and DHA (Yamaguchi, 1997; Spolaore et al., 2006). The data presented in Table 4 show that increasing inclusion of all algae caused a decline in lipid digestibility. The highest inclusion level resulted in significantly lower lipid digestibility than any other diets within the same alga (Table 4). The lowest lipid digestibility was observed for the diet containing the highest level of N. oceanica. Characteristically, lipid digestibility was more variable for diets containing $N$. oceanica and I. galbana than for diets with $P$. tricornutum, and the variation increased greatly with increasing levels of algae products. Thus, the standard deviations for percentage lipid digestibility were 0.14 for the fish meal control diet, and 8.46, 2.49 and 
6.46 for diets containing the highest levels of $N$. oceanica, P. tricornutum and I. galbana, respectively.

As shown in Table 2, all algae represented a rather minor proportion of total dietary lipids. Soyabean oil was the major source of lipids in all diets, and fish meal also provided larger proportional levels of lipids than the algae, except for the diet containing the highest level of I. galbana. Still all algae appeared to cause a progressively declining lipid digestibility with increasing inclusion of algae lipids (Table 4; Figure 2). Although P. tricornutum could be fed at $24 \%$ as

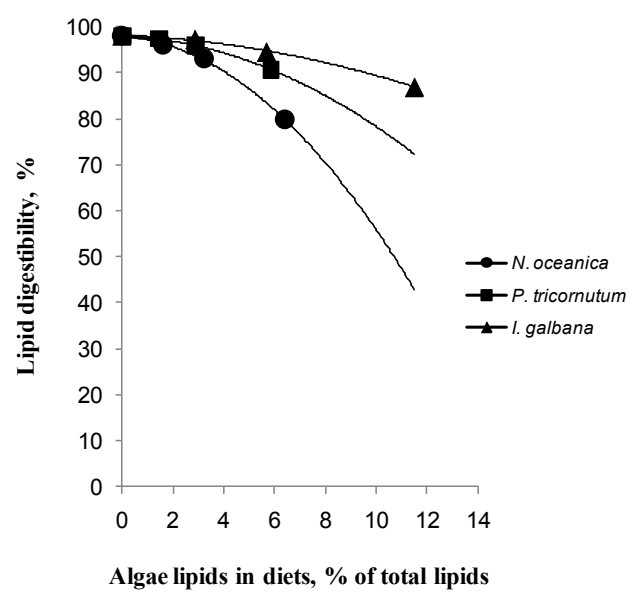

Figure 2. Regression lines for apparent digestibility of lipids in the three microalgae ( $y=$ apparent digestibility of a diet with $\mathrm{x} \%$ of lipids from the algae). Nannochloropsis oceanica (- $\bullet-)$; $\mathrm{y}=-0.3841 \mathrm{x}^{2}-0.3724 \mathrm{x}+97.962\left(\mathrm{R}^{2}=0.9989\right)$. Phaeodactylum tricornutum $(-\mathbf{-}-) ; \mathrm{y}=-0.1732 \mathrm{x}^{2}$ $-0.2497 \mathrm{x}+98.107\left(\mathrm{R}^{2}=1.0\right)$. Isochrysis galbana $(-\mathrm{m}-) ; \mathrm{y}=-0.0653 \mathrm{x}^{2}-0.2266 \mathrm{x}+98.205$ $\left(\mathrm{R}^{2}=0.9982\right)$

is with moderate negative effects on digestibility of dietary lipids, a regression analysis of lipid digestibility of all algae resulted in negative values. This curvilinear relationship was surprising and can only be explained by negative effects of components in the algae on lipid digestibility. These components are unlikely to be lipids; hence the lipid digestibilities in Table 4 may give no information about digestibility of the inherent algae lipids. Noteworthy, Bitou et al. (1999) reported lipase inhibitor activity in a number of marine algae and identified the terpene caulerpenyene as an active inhibitor interacting directly with the lipase protein. The resistance of the complex algal cell wall structure to digestive enzymes may inhibit lipid digestion, and cell wall constituents may also affect digestion of other lipids in the diets than those derived from algae. It 
is concluded that the lipid digestibility as well as protein digestibility might have been improved by using an adequate processing technique to rupture the cell walls prior to inclusion of the algae in the compound feed. The microalgae had very different digestibility of protein and amino acids, and different effects on lipid digestibility. Among the investigated freeze-dried algae, P. tricornutum should be the preferred feed ingredient for monogastric animals including salmonid fish, due to the high digestibility of crude protein and individual amino acids, and only minor negative effect on lipid digestibility if fed at moderate levels.

\section{REFERENCES}

Albentosa M., Pèrez-Chamacho A., Labarta U., Fernàndez-Reiriz, M.J., 1997. Evaluation of freezedried microalgal diets for the seed culture of Ruditapes decussatus using physiological and biochemical parameters. Aquaculture 154, 305-321

Alonso D.L., Belarbi E.-H., Fernàndez-Sevilla J.M., Rodriguez-Ruiz J.R., Grima E.M., 2000. Acyl lipid composition variation related to culture age and nitrogen concentration in continuous culture of the microalga Phaeodactylum tricornutum. Phytochem. 54, 461-471

Becker E.W., 2007. Micro-algae as a source of protein. Biotechnol. Adv. 25, 207-210

Bitou N., Ninomiya M., Tsujita T., Okuda H., 1999. Screening of lipase inhibitors from marine microalgae. Lipid 34, 441-445

Brown M.R., 1991. The amino-acid and sugar composition of 16 species of microalgae used in mariculture. J. Exp. Mar. Biol. Ecol. 145, 79-99

Brown M.R., 2002. Nutritional value of microalgae for aquaculture. In: L.E. Cruz-Suàrez, D. Ricque-Marie, M. Tapia-Salazar, M.G. Gaxiola-Cortès, N. Simoes (Editors). Avances en Nutriciòn Acuicola VI. Memorias del VI Simposium Internacional de Nutriciòn Acuicola. 3 al 6 de Septiembre del 2002. Cancùn, Quintana Roo, Mèxico

Brown M.R., Garland C.D., Jeffrey S.W., Jameson I.D., Leroi J.M., 1993. The gross and amino acid compositions of batch and semi-continuous cultures of Isochrysis sp. (clone T.ISO), Pavlova lutheri and Nannochloropsis oculata. J. Appl. Phycol. 5, 285-296

Brown M.R., Jeffrey S.W., Volkman J.K., Dunstan G.A., 1997. Nutritional properties of microalgae for mariculture. Aquaculture 151, 315-331

Epifanio C.E., 1979. Growth in bivalve molluscs: Nutritional effects of two or more species of algae in diets fed to the American oyster Crassostrea Virginica (Gmelin) and the hard clam Mercenaria mercenaria (L.). Aquaculture 18, 1-12

Fàbregas J., Otero A., Morales E.D., Arredondo-Vega B.O., Patino M., 1998. Modification of the nutritive value of Phaeodactylum tricornutum for Artemia sp. in semicontinuous cultures. Aquaculture 169, 167-176

Janczyk P., Wolf C., Souffrant W.B., 2005. Evaluation of nutritional value and safety of the green microalgae Chlorella vulgaris treated with novel processing methods. Arch. Zootech. 8, 132147

Marshall R., McKinley S., Pearce C.M., 2010. Effects of nutrition on larval growth and survival in bivalves. Rev. Aquacult. 2, 33-55

McCleary B.V., Solah V., Gibson T.S., 1984. Quantitative measurements of total starch in cereal flours and products. J. Cereal Sci. 20, 51-58 
Miròn A.S., Garcia M.C.C., Gòmez A.C., Camacho F.G., Grima E.M., Chisti Y., 2003. Shear stress tolerance and biochemical characterization of Phaeodactylum tricornutum in quasi steady-state continuous culture in outdoor photobioreactors. Biochem. Eng. J. 16, 287-297

Pettersen A.K., Turchini G.M., Jahangard S., Ingram B.A., Sherman C.D.H., 2010. Effects of different dietary microalgae on survival. Growth, settlement and fatty acid composition of blue mussel (Mytilus galloprovincialis) larvae. Aquaculture 309, 115-124

Rebolloso-Fuentes M.M., Navarro-Pèrez A., Garcia-Camacho F., Ramos-Miras J.J., Guil-Guerro J.L., 2001. Biomass nutrient profiles of the microalga Nannochloropsis. J. Agr. Food Chem. 49, 2966-2972

Reitan K.I., Rainuzzo J.R., Olsen Y., 1994. Effect of nutrient limitation on fatty acid and lipid content of marine microalgae. J. Phycol. 30, 972-979

Saleh A.M., Hussein L.A., Abdalla F.E., El-Fouly M.M., Shaheen A.B., 1985. The nutritional quality of drum-dried algae produced in open door mass culture. Z. Ernährungswiss. 24, 256-263

Sandnes J.M., Källqvist T., Wenner D., Gislerød H.R., 2005. Combined influence of light and temperature on growth rates of Nannochloropsis oceanica: linking cellular responses to largescale biomass production. J. Appl. Phycol. 17, 515-525

Sànchez S., Martinez E., Espinola F., 2000. Biomass production and biochemical variability of the marine microalga Isochrysis galbana in relation to culture medium. Biochem. Eng. J. 6, 13-16

Skrede A., 1979. Utilization of fish and animal byproducts in mink nutrition. IV. Fecal excretion and digestibility of nitrogen and amino acids by mink fed cod (Gadus morhua) fillet or meat-andbone meal. Acta Agr. Scand. 29, 241-257

Skrede A., Berge G.M., Storebakken T., Herstad O., Aarstad K.G., Sundstøl F., 1998. Digestibility of bacterial protein grown on natural gas in mink, pigs, chicken and Atlantic salmon. Anim. Feed Sci. Tech. 76, 103-116

Spolaore P., Joannis-Cassan C., Duran E., Isambert A., 2006. Review. Commercial application of microalgae. J. Biosci. Bioeng. 101, 87-96

Szymeczko R., Skrede A., 1990. Protein digestion in mink. Acta Agr. Scand. 40, 189-200

Yamaguchi K., 1997. Recent advances in microalgal bioscience in Japan, with special reference to utilization of biomass and metabolites: a review. J. Appl. Phycol. 8, 487-502 